\title{
ROLE OF C-REACTIVE PROTEIN IN PRE-OPERATIVE EVALUATION OF ACUTE APPENDICITIS
}

\author{
Noorudheen N. K' Ramesh P. K², S. Muneeruddin Ahmed ${ }^{3}$
}

${ }^{1}$ Assistant Professor, Department of General Surgery, KMCT Medical College, Manassery, Kozhikode, Kerala. ${ }^{2}$ Assistant Professor, Department of General Surgery, KMCT Medical College, Manassery, Kozhikode, Kerala. ${ }^{3}$ Professor, Department of ENT, Kannur Medical College, Kannur.

\begin{abstract}
Acute appendicitis is the most common abdominal surgical emergency in developed countries with peak incidence between 1030 years, and the incidence of the disease is increasing in developing countries. By adulthood one in six people would have undergone removal of their appendix. The diagnosis of acute appendicitis sometimes remains as a challenge despite advances in imaging and laboratory investigations. Studies have shown that appendicitis is associated with elevated C-reactive protein. Elevated C-reactive protein along with Leucocytosis and high neutrophil ratio provides satisfactory specificity and positive predictive value in its diagnosis.
\end{abstract}

\section{AIM OF THE STUDY}

To study the correlation between the serum C- reactive protein levels and the grades of inflammation in Acute Appendicitis per operatively and on histopathological study.

\section{MATERIALS AND METHODS}

One hundred patients undergoing Emergency appendicectomy in the surgical casualty following diagnosis were included. Serum levels of C-reactive protein is estimated pre-operatively in all the patients and correlated with inflammatory grading per operative and histopathological studies of the excised specimens.

\section{OBSERVATIONS}

There were 65 males and 35 female patients. More than $70 \%$ of the patients belonged to the age group of below 30 years. 38 patients showed minimal inflammation as against 41 patients with highly inflamed appendices. Appendicle perforation was found in 10 patients. Raised serum $C$ reactive protein levels were found in 51 patients who showed highly inflamed appendices and its complications.

\section{RESULTS}

Serum C- reactive protein were higher in the patients who showed highly inflamed appendices per operatively and on histopathological examination of the specimen.

\section{CONCLUSIONS}

CRP was high [ $>6 \mathrm{mg} \%$ ] in 64 of the 77 patients who had histologically proven acute appendicitis and in 2 with normal appendix. The sensitivity and specificity were $83.11 \%$ and $91.3 \%$ respectively. When Leucocytosis and shift to left combined with high level of serum CRP, diagnostic accuracy of acute appendicitis is high.

\section{KEYWORDS}

Appendix, Surgery, Appendicectomy, C Reactive Protein, Investigation.

HOW TO CITE THIS ARTICLE: Noorudheen NK, Ramesh PK, Ahmed SM. Role of C-reactive protein in pre-operative evaluation of acute appendicitis. J. Evolution Med. Dent. Sci. 2016;5(37):2202-2206, DOI: 10.14260/jemds/2016/512

\section{INTRODUCTION}

Acute appendicitis, when presenting in a teenager and with a classical history, presents the surgeon with little by way of a diagnostic challenge. However, this disease is notorious in its ability to simulate other conditions in the frequency with which it too can be imitated by other pathologies. The variations in the pathophysiological development of the disease, coupled with the wide range of possible positions of the organ, may explain why only nearly half of patients presents with typical history. ${ }^{1}$

Financial or Other, Competing Interest: None.

Submission 22-03-2016, Peer Review 18-04-2016,

Acceptance 23-04-2016, Published 07-05-2016.

Corresponding Author:

Dr. S. Muneeruddin Ahmed,

44/118, Prakash Nagar,

Kurnool-518 004.

E-mail: ahmedmunirent@gmail.com

DOI: $10.14260 /$ jemds $/ 2016 / 512$
Nevertheless, unnecessary appendicectomy is not altogether without problems. There will be a small incidence of wound sepsis and the subsequent adhesive intestinal obstruction and Incisional hernia. More important is the situation where the operation fails to relieve the patients' symptoms and so has wasted everyone's time and, in addition caused him (Or more her) inconvenience and suffering without therapeutic gain $\mathbf{1}$. The emergency surgeon must also remember that "one can't step twice into the same river" and that the patient with acute right iliac fossa pain, and a scar into the bargain, is not the same patient psychologically or physically as before. ${ }^{2}$ The emergency surgeon must appreciate that the decision that needs to be made when considering the possibility of appendicitis is not whether the diagnosis is correct but whether an operation is indicated. ${ }^{3}$ the diagnosis may not be difficult when presenting with typical symptoms and signs. 
Diagnostic difficulty in patient with atypical clinical findings has resulted in unnecessary appendicectomy surgeries, which have been variably reported in the literature with an average of about $20 \%$. In fact, the rate of negative appendicectomy operations increases to 35 to $45 \%$ in young women of child bearing age in whom differential diagnosis from pelvic inflammatory disease may be extremely difficult. So traditionally, surgeons have accepted a higher incidence of unnecessary appendicectomies in order to decrease the incidence of perforation. ${ }^{4}$ this approach is being increasingly questioned in today's era of cost effective health care. The high rate of negative explorations for appendicitis are a burden faced not only by the general surgeon, but also the patient and the society as a whole, since appendicectomy, like any other operation, results in socio-economic impacts in the form of hospital expenses, lost working days, and declined productivity.

The goal of surgical treatment is removal of an inflamed appendix before perforation with a minimal number of negative appendicectomies. Many studies have shown that appendicitis is associated with elevated C-reactive protein. Elevated C-reactive protein along with Leucocytosis and high neutrophil ratio provides satisfactory specificity and positive predictive value in diagnosing acute appendicitis. ${ }^{5} \mathrm{~A}$ normal preoperative serum CRP measurement is most likely associated with a normal appendix and deferring surgery in this group of patients would probably reduce the rate of unnecessary appendicectomy operations. ${ }^{6}$

This prospective study is aimed to determine if CRP estimation in preoperative diagnosis of acute appendicitis stands as a reliable laboratory investigation. The study involves pre-operative estimation of serum CRP in patients admitted with acute appendicitis and comparing the serum CRP level with the intra operative findings and the histopathological report, which is taken into account as the final diagnosis. The study group involves those patients who underwent emergency open appendicectomy in Department of general surgery, Government Medical college hospital, Kozhikode during the period from February 2011 to November 2011.

\section{OBJECTIVES OF THE STUDY}

To estimate pre-operative serum CRP level in patients with clinical diagnosis of acute appendicitis. To compare the preoperative serum CRP level with the final histopathological diagnosis. To find out relation between serum CRP level and related complications of Acute Appendicitis like gangrene formation or and perforation.

\section{MATERIALS AND METHODS}

This Cross sectional study was conducted in the Department of General Surgery of Medical College, Kozhikode between February 2011 and November 2011. The Sample size was 100 patients.

\section{Inclusion Criteria}

Patients diagnosed with acute appendicitis and undergoing emergency appendicectomy in Surgical Casualty. Patients of all age groups were included.

\section{Exclusion Criteria}

Patients who were treated conservatively. Patients with inflammatory bowel disease, connective tissue disorders like rheumatoid arthritis. C - reactive protein - Serum samples from all the patients admitted with acute appendicitis are collected and quantitative determination of C-reactive protein in serum by means of particle-enhanced turbidimetric immunoassay was done. Excised appendices were subjected to histopathology final confirmation of the diagnosis. The patients were admitted with suspected diagnosis of acute appendicitis based on their clinical history and physical examinations were included. Serum CRP estimation was done in all these patients prior to surgery. The serum CRP level is compared and correlated with the final histopathological diagnosis and severity of acute appendicitis which was graded as minimally inflamed, grossly inflamed, perforated with local peritonitis, gangrene formation or sloughed off. Standard statistical methods were applied to arrive at conclusion.

\section{OBSERVATIONS AND RESULTS}

One hundred patients diagnosed and treated surgically for Acute Appendicitis were analysed in the present study. Patients were grouped as below 20 years of age and above 40 years of age, and the remaining patients were grouped at class intervals of 10 . There were 38 patients (30\%) aged below 20 years, 41 patients (41\%) in the age group of 21 to 30,16 patients (16\%) in the age group of 31 to 40 and 5 were above 40 years (Table 1 ).

\begin{tabular}{|c|c|c|}
\hline \multicolumn{3}{|c|}{ Age Group } \\
\hline & Frequency & Percent \\
\hline Valid =<20 Yrs. & 38 & 38.0 \\
\hline $21-30$ & 41 & 41.0 \\
\hline $31-40$ & 16 & 16.0 \\
\hline$>40$ yrs & 5 & 5.0 \\
\hline Total & 100 & 100.0 \\
\hline $\begin{array}{r}\text { Table 1: Showing } \\
\text { in Var }\end{array}$ & $\begin{array}{l}\text { idence of Ac } \\
\text { e Groups (n }\end{array}$ & endicitis \\
\hline
\end{tabular}

There were 65 male patients (65\%) and 35 female patients (35\%) in the study group (Table 2).

\begin{tabular}{|c|c|c|}
\hline \multicolumn{3}{|c|}{ Sex } \\
\hline & Frequency & Percent \\
\hline Valid Male & 65 & 65.0 \\
\hline Female & 35 & 35.0 \\
\hline Total & $\mathbf{1 0 0}$ & 100.0 \\
\hline Table 2: Showing the Sex Incidence of Acute \\
Appendicitis (n=100) \\
\hline
\end{tabular}

All the patients were operated upon by the senior surgeons of the Department and during surgery the condition of the appendix was noted and recorded and graded as minimally inflamed (38\%), grossly inflamed (42\%), perforated with local peritonitis $(10 \%)$, gangrene formation (8\%) and sloughed off type (2\%), (Table 3).

\begin{tabular}{|c|c|c|}
\hline & Frequency & Percent \\
\hline Minimally inflamed & 38 & 38.0 \\
\hline Grossly inflamed & 42 & 42.0 \\
\hline $\begin{array}{l}\text { Perforated with } \\
\text { Local peritonitis }\end{array}$ & 10 & 10.0 \\
\hline Gangrenous & 8 & 8.0 \\
\hline Sloughed off & 2 & 2.0 \\
\hline Total & 100 & 100.0 \\
\hline \multicolumn{3}{|c|}{$\begin{array}{c}\text { Table 3: Showing the Grading of the Inflammation i the } \\
\text { Appendix During Surgery }(n=100)\end{array}$} \\
\hline
\end{tabular}


All the specimens following appendicectomy were subjected to Histo-pathological study and it was found that Histologically unremarkable in $18 \%$ pf the patients, Acute appendicitis in 69\%, lymphoid hyperplasia in 55, Acute appendicitis with perforation in $3 \%$, gangrenous changes in $3 \%$, carcinoid in $1 \%$ and eosinophilic appendicitis in $1 \%$ of them (Table 4).

\begin{tabular}{|c|c|c|}
\hline & Frequency & Percent \\
\hline Histologically unremarkable & 18 & 18.0 \\
\hline Ac Appendicitis & 69 & 69.0 \\
\hline Lymphoid hyperplasia & 5 & 5.0 \\
\hline Ac appendicitis with perforation & 3 & 3.0 \\
\hline Gangrenous & 3 & 3.0 \\
\hline Carcinoid & 1 & 1.0 \\
\hline Eosinophilic appendicitis & 1 & 1.0 \\
\hline Total & 100 & 100.0 \\
\hline \multicolumn{3}{|c|}{$\begin{array}{l}\text { Table 4: Showing the Histo-Pathological } \\
\text { Reports }(n=100)\end{array}$} \\
\hline
\end{tabular}

Pre-Operative serum levels of $\mathrm{C}$-reactive protein were correlated with the Per-operative signs of inflammation of the Appendix and the related data is shown in the Table 5.

\begin{tabular}{|c|c|c|c|}
\hline \multicolumn{4}{|c|}{ Descriptives } \\
\hline & $\mathbf{N}$ & Mean & $\begin{array}{c}\text { Std. } \\
\text { Deviation }\end{array}$ \\
\hline Minimally & 38 & 5.266 & 16.787 \\
\hline Grossly Inflamed & 42 & 38.229 & 42.145 \\
\hline $\begin{array}{c}\text { Perforated with Local } \\
\text { Peritonitis }\end{array}$ & 10 & 107.650 & 89.692 \\
\hline Gangrenous & 8 & 59.313 & 48.150 \\
\hline Sloughed of & 2 & 40.600 & 30.264 \\
\hline \multicolumn{3}{|c|}{$\begin{array}{c}\text { Table 5: Showing the Correlatio betweeen the } \\
\text { Inflammation of the Appendix and the C- reactive } \\
\text { Protein (n=100) }\end{array}$} \\
\hline
\end{tabular}

Similarly the C-reactive protein levels and the Histopathological reports of the study group subjects was done. The related data is shown in the Table 6.

\begin{tabular}{|c|c|c|c|}
\hline \multicolumn{4}{|c|}{ Descriptives } \\
\hline & $\mathbf{N}$ & Mean & $\begin{array}{c}\text { Std. } \\
\text { Deviation }\end{array}$ \\
\hline $\begin{array}{c}\text { Histologically } \\
\text { Unremarkable }\end{array}$ & 18 & 2.428 & 3.759 \\
\hline Ac Appendicitis & 69 & 38.984 & 49.029 \\
\hline Lymphiod Hyperplasia & 5 & .760 & .921 \\
\hline $\begin{array}{c}\text { Ac Appendicitis with } \\
\text { Perforation }\end{array}$ & 3 & 106.167 & 74.350 \\
\hline \multicolumn{6}{|c|}{ Gangrenous } & 3 & 117.667 & 115.647 \\
\hline Carcinoid & 1 & 26.800 &. \\
\hline $\begin{array}{c}\text { Eosinophilic } \\
\text { Appendicitis }\end{array}$ & 1 & 2.200 &. \\
\hline & $\begin{array}{c}\text { Table 6: Showing the Correlation between the } \\
\text { C - reactive protein ND the Histo- } \\
\text { Pathological Reports (n=100) }\end{array}$ \\
\hline
\end{tabular}

A high positive correlation between $C$ - reactive protein and histopathological reports in 51 patients and a negative correlation in 2 patients was observed. A positive correlation was observed in 2 of the patients with near normal appendices and negative in 23 of them. In others the correlation was equivocal (Table 7).

\begin{tabular}{|c|c|c|}
\hline \multirow{2}{*}{ CRP } & \multicolumn{2}{|c|}{ Histopathology } \\
\cline { 2 - 3 } & Positive & Negative \\
\hline High & 51 (a) & 2 (b) \\
\hline Normal & 2 (c) & 23 (d) \\
\hline \multicolumn{2}{|c|}{ Table 7: Showing the correlation of } \\
C-reactive protein and HPE (n=100)
\end{tabular}

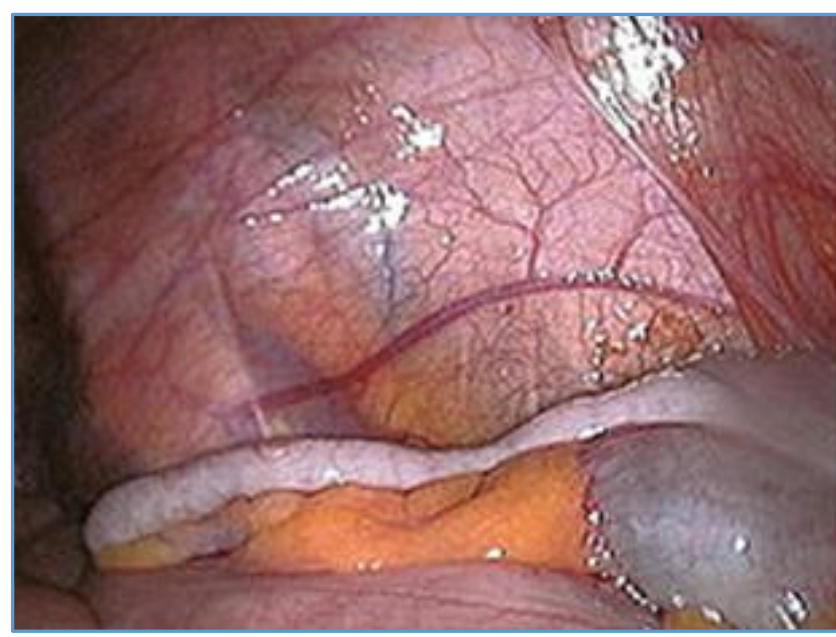

Fig. 1: Laparoscopic view of Appendix

\section{DISCUSSION}

Appendicitis is the most common abdominal surgical emergency and appendicectomy is one of the most frequently performed abdominal operations. The high rate of negative explorations for appendicitis is in the range of $15-30 \%$. This is a burden faced not only by the general surgeon, but also the patient and the society as a whole, since appendicectomy, like any other operation, results in socio-economic impacts in the form of hospital expenses, lost working days, and declined productivity. ${ }^{7}$ Pain abdomen and vomiting are the predominant clinical symptoms in cases of acute appendicitis. But they are not specific for acute appendicitis. Migration of pain, which is present in only about one fourth of the cases, is more specific for acute appendicitis..$^{8}$ the presence of fever increases the diagnostic accuracy.

Tachycardia which is commonly seen in patients with acute appendicitis may also be seen in many other conditions. Right iliac fossa tenderness is present in all the cases, but is not specific for acute appendicitis. Rebound tenderness and guarding if present, are more specific for acute appendicitis. Leucocytosis is present in around three fourths of the patients with acute appendicitis. ${ }^{9}$ but it is elevated in other inflammatory conditions as well. Differential count shows neutrophilia in most cases of acute appendicitis. Leucocytosis and urine microscopy do not provide high accuracy in diagnosis of acute appendicitis. The Alvarado score is a 10point scoring system based on clinical signs and symptoms and a differential leukocyte count.10

Alvarado recommended an operation for all patients with a score of 7 or more and observation for patients with scores of 5 or $6.10 \mathrm{~A}$ high score was found to be an easy and satisfactory aid to early diagnosis of acute appendicitis in children and men, but had a high false-positive rate in women. But various studies have shown the scoring system to be not particularly advantageous. Ultrasonography is a useful adjunct in diagnosis of acute appendicitis. Ultrasound equipment is often not available to aid a surgeon in a rural setting. And 
accuracy of Ultra sonography (USG) is operator dependent and inter-observer variation is a disadvantage. ${ }^{11}$ the main advantage of USG is establishment of an alternative diagnosis. The spectrums of alternative diagnoses that mimic appendicitis is broad and include gynaecological diseases, inflammatory and infectious diseases of bowel, cholecystitis, malignancy, diseases of liver, spleen, pancreas and urological disorders.

But an alternate diagnosis does not exclude acute appendicitis. Despite extra-ordinary advances in radiographic imaging and diagnostic laboratory investigations, the diagnosis of acute appendicitis remains an enigmatic challenge. ${ }^{12}$ Diagnostic laparoscopy, Computerised Tomography scan, Technitium-99m study, and Magnetic Resonance Imaging are few investigations which had infused initial enthusiasm in the past and later were found to be of moderate reliability or poorly cost effective. ${ }^{13}$ C-reactive protein has been a measure of acute phase reactions to inflammation

For the last 15 years. CRP can be measured in the serum 6 - 12 hours after the onset of inflammatory process. Recently improved high sensitive and standardised quantitative assays in serum have allowed a re-evaluation of its potential as a diagnostic test. ${ }^{14}$ Many studies have investigated the role of CRP in improving the diagnosis of acute appendicitis. In present study, serum CRP estimation in diagnosis of acute appendicitis yielded a sensitivity of $83.11 \%$ and specificity of 91.3\%. Asfar S, Safar H et al have found that the specificity and sensitivity of serum CRP in the diagnosis of acute appendicitis was $86.6 \%$ and $93.6 \%$ respectively. ${ }^{15}$ which is comparable with present study. The sensitivity and specificity of present study are weighed against other studies in Table 7.

It is shown that the sensitivity and specificity values are comparable with that of other studies done in the past. This study proves the adjunct value of serum CRP estimation in suspected cases of acute appendicitis. The present study involves Serum CRP estimation because of its ease of applicability, availability even in rural settings and cost effectiveness is rapidly emerging as a diagnostic tool with proven use. Being an acute phase reactant, CRP may be elevated in other conditions as well, and hence the specificity of CRP is low. CRP is the earliest to measure inflammatory marker because of its dramatic rise in response to inflammation and is always associated with pathological condition.

CRP values have been found to rise on repeated testing, whereas WBC values decreased. CRP values when combined with other inflammatory markers like Leucocytosis and neutrophilia and with clinical examination, provides high sensitivity and specificity rates. Serum CRP estimation in acute appendicitis yielded a false negative rate of $16.88 \%$ in the present study, which is significantly high when compared with other studies. False negative reactions usually occur early in the infective episode only. Other reasons are due to technical pitfalls in laboratory testing. Because CRP levels can increase so rapidly and dramatically, the latex agglutination assay is subject to false-negative reactions due to a prozone-type phenomenon in which all of the antibody combining sites on the latex particles are bound to an excess of CRP, so no crosslinking (Agglutination) can occur.16 This can be avoided by performing qualitative tests on several dilutions.
Thus, at the end, it should be stressed that serum CRP estimation does not replace clinical diagnosis, but is useful adjunct in diagnosis of acute appendicitis. Clinical diagnosis is crucial in ruling out alternate diagnoses and other conditions which might give a false positive value on CRP estimation. Serum CRP value should be interpreted in combination with clinical findings and leukocyte count. 17 Sonography is extremely useful if facilities are available, but adds to the cost of patient care. Thus, serum CRP estimation does not undermine the importance of clinical diagnosis by a skilled surgeon, but compliments it.

\section{CONCLUSIONS}

Acute appendicitis is the most common abdominal surgical emergency, but its diagnosis remains an enigmatic challenge, plagued by a high rate of negative explorations. There is no single reliable test with satisfactory sensitivity and specificity. This study is intended to evaluate the importance of serum CRP level estimation in the diagnosis of acute appendicitis, by comparing with final histopathology report. In a prospective study, 100 patients clinically diagnosed as acute appendicitis, and underwent emergency appendicectomy in Government Medical College Hospital, Kozhikode were selected, serum CRP levels estimated and were followed up postoperatively with histopathology reports. The data was analysed for finding the significance of serum CRP in the diagnosis of acute appendicitis.

CRP was high [ $>6 \mathrm{mg} \%]$ in 64 of the 77 patients who had histologically proven acute appendicitis and in 2 with normal appendix. The sensitivity and specificity were $83.11 \%$ and 91.3\% respectively. When Leucocytosis and shift to left combined with high level of serum CRP, diagnostic accuracy of acute appendicitis is high. CRP contains important diagnostic information and hence should always be included in the diagnostic workup of acute appendicitis. Since acute appendicitis is very unlikely in those patients with normal WBC count and CRP level, conservative treatment is recommended. This study does not undercut the skill of an experienced surgeon in diagnosing acute appendicitis, but CRP estimation is a cost-effective investigation which compliments clinical diagnosis.

\section{REFERENCES}

1. Brown SP. Acute appendicitis. In: Ellis BW, Brown SP, editors. Hamilton bailey's emergency surgery, New York: Arnold 2000;13 th ed:399-400.

2. John Maa, Kimberly S Kirkwood, Appendix. In: Sabiston text book of surgery: ey M. Townsend (Ed) 2008;18 th ed:1021-25.

3. Rosemary A, Kozar, Joel J Roslyn. The appendix, In: Schwartz's principles of surgery; Schwartz SI (Ed), Mc Graw Hill 7th ed;786-94.

4. Sir Alfred cuschieri, Robort TC Skele, Abdool Rahim moosa. Essential surgical practice $4^{\text {th }}$ ed;957-59.

5. Duff SE, Dixon AR. Laparoscopic appendicectomy: safe and useful for training. Ann $\mathrm{R}$ Coll Surg Engl 2000;82(6):388-91.

6. Sauerland S, Lefering R, Neugebauer EA. Laparoscopic versus open surgery for suspected appendicitis. Cochrane Database Syst Rev 2004;4:CD001546. doi:10.1002/14651858.CD001546. 
7. May EA. Chronic appendicitis: its roentgen diagnosis. J Med Soc NJ 1937;34:91.

8. Wakeley CPG. The position of the vermiform appendix as ascertained by an analysis of 10,000 cases. J Anat 1933;67(2):277-83.

9. Maisel $\mathrm{H}$. The position of the human vermiform appendix in fetal and adult age groups. Anat Rec 1960;136(3): 385-91.

10. Alvarado A. A practical score for the early diagnosis of acute appendicitis. Ann Emerg Med 1986;15(5):557-64.

11. Morgagni JB. The seats and causes of disease investigated by anatomy. Alexander LB (Trans). New York: Hafner publishing 1960;176-8.

12. Collins DC. 71,000 human appendix specimens: a final report, summarizing forty years' study. Am J Proctol 1963;14:265-81.
13. Collins DC. The chronic inflammatory and obliterative reactions of the vermiform appendix. Thesis, ed. Postgraduate school, university of minnesota 1932;119-22.

14. Schridde H. Über den angeborenen mangel des processus vermiformis. Virchows Archiv für pathologische Anatomie und Physiologie und für klinische Medizin 1904;177(1):150-66.

15. Williams RA. Development, structure and function of the appendix. In: Williams RA, Myers P. Pathology of the appendix and its surgical treatment. New York: Chapman \& Hall Medical 1994;p 9-30.

16. Fenoglio-Preiser CM, Lantz PE, Listrom MB. Gastrointestinal pathology: An anthology and text. New York: Raven press, 1989;235-37.

17. Chevre F, Gillet M, Vuilleumier H. Agenesis of the vermiform appendix. Surg Laparosc Endosc Percutan Tech 2000;10(2):110-2. 